\author{
B.S. Dzundza, V.V. Prokopiv, T.M. Mazur, L.D. Yurchyshyn
}

\title{
Automation of measurements of photoelectric parameters of high-impedance semiconductor films
}

\author{
Vasyl Stefanyk Precarpathian National University \\ 57, Shevchenko Str., Ivano-Frankivsk, 76025, Ukraine, E-mail: prkvv@i.ua
}

\begin{abstract}
A method of measuring electrical conductivity and photoconductivity of semiconductor films with high electrical resistance has been described. The electric circuit has been presented and the computer program has been developed. That provides automation of measurements, registration and primary processing of data with possibility of plotting time dependences for preliminary analysis of experimental data during measurement.
\end{abstract}

Key words: electrical parameters, photoconductivity, automation, microcontroller.

Article acted received 11.09.2018; accepted for publication 15.12.2018.

\section{Introduction}

The problem of measuring electrical and photovoltaic parameters of semiconductor materials, in particular, II-VI compounds, is relevant due to the prospect of their use for the creation of gamma and hard X-ray detectors and as infrared filters [1]. CdTe thin films are used to make solar panels [2]. Recently, interest in quantum dots based on CdTe has also increased.

Typical values of resistivity of these materials are $10^{8}-10^{9} \Omega \cdot \mathrm{cm}$ [3], and the study of the electrical parameters of such samples requires a precision and expensive electrometric equipment and is rather timeconsuming.

In recent decades, there is rapid development of microprocessor and computer technology, which opens up new opportunities for automation of technological processes and laboratory research. The emergence of new specialized microcircuits and microcontrollers with a large amount of memory, a well-developed peripherals and low price, combined with mastering simplicity, makes their use in automated measuring systems optimal.

In this paper, the electric circuit is presented and the computer program is developed that provides automation of measurements of conductivity, photoconductivity and current-voltage characteristics of semiconductor films with an electrical resistance up to $500 \mathrm{G} \Omega$, registration and primary processing of the received data.

\section{Measurement Method}

Measurement of electrical parameters of semiconductor films is carried out according to the classical technique, when a sufficiently high voltage is applied to the sample, and the current that flows through the sample is measured. During the measuring the film samples were placed in the standard design holders [4] made on a fluoroplastic basis with four measuring probes and integrated reference resistor to measure current with digital microvoltmeter. The holder via the releasable connection is fixed in the middle of the aluminum cylinder, in which a precision temperature sensor, a digital light meter and a light source of appropriate frequency are built-in. The temperature range in the working area was $77-500 \mathrm{~K}$. The accuracy of the temperature measurement was $0.5 \mathrm{~K}$, the illumination measurement - $\pm 3 \%$, conductivity measurement $\pm 10 \%$. The low temperature cryostats were quartz Dewar flask or styrofoam vessels filled with liquid nitrogen. The intermediate temperatures between liquid nitrogen and room temperatures were reached by heating using a bifilar wound nichrome spiral.

Making reliable ohmic contacts, which do not destroy the film and satisfy all the necessary requirements [4,5], was carried out by silver deposition methods in combination with gilded contact pins or soldering at $\mathrm{T}<400 \mathrm{~K}$. The choice of the main contact material was determined by its work output, temperature and mechanical properties. Silver, silver paste were used for soldering as ohmic contact to films of hole conductivity, and indium was used for films of electron conductivity. Silver and copper wires of (0.01-0.05) mm in diameter were used as connecting elements. To reduce the overall electrical resistance of the film material, the contacts were deposited in the form of rectangles at a short distance from each other (Fig. 1). Control of the properties of the made contacts was carried out by 
analyzing the current-voltage characteristics of the samples [3]. Type of conductivity was determined by the sign of thermo-emf [3]. The thickness of the thin films was determined by the optical method using the microinterferometer MII-4. At the same time, accuracy was was $\sim 0.02 \mu \mathrm{m}$.

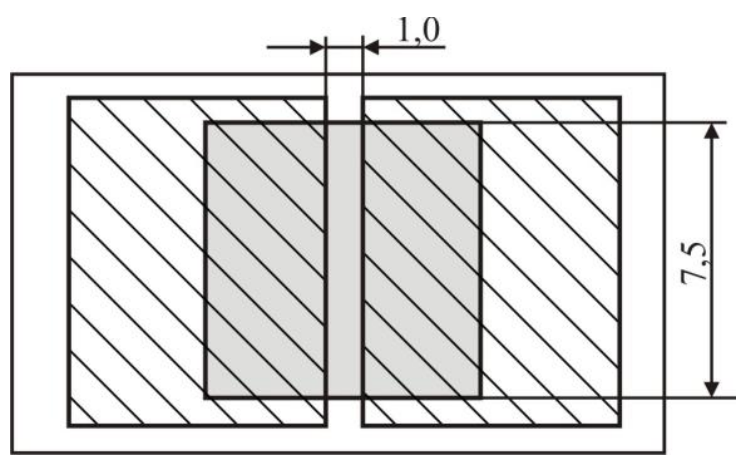

Fig. 1. The possible configuration of the sample for measuring the electrical parameters of the thin films.

\section{Schematic of the device}

The functional scheme of the device is shown in Fig. 2. The basis of the measuring system is a digital multimeter UNI-T UT804, which supports the output of data on the computer and in the mode of voltmeter of constant voltage, provides a resolution of $0.01 \mathrm{mV}$ with accuracy of $0.05 \%$ and has a mode of automatic selection of measuring range.

Microcontroller STM32152C8T6 was chosen as a controller, which is characterized by a well-developed periphery. In particular, it has a built-in USB hardware for communication with the computer, a multichannel 12-bit analog-to-digital converter (ADC) for digitizing analog signals from the thermistor, shunts, a sufficient amount of memory and outputs. The use of this microcontroller has made it possible not only to implement the task, but also to leave a resource for further modernization and expansion of functionality. The program for the microcontroller is written in C.

Communication with the computer at the hardware level is carried out via the built-in USB microcontroller, and at the software level - with the help of the text command interpreter, which provides two-way data exchange between the control program on the computer and the microcontroller of the device.

The high-voltage generator is assembled on the OZ960 microcircuit (Fig. 3) in the standard setting and configured so that when the load on a chain of 4 resistors with a total resistance of $200 \mathrm{k} \Omega$ it produces a voltage of $1200 \mathrm{~V}$, various voltages are measured at the resistor taps, rectified by a high-voltage fast diode, smoothed by a capacitor and applied to the sample via the switching node. Turning on the voltage supply to the sample is implemented with the use of electromechanical relays controlled by a microcontroller or carried out manually.

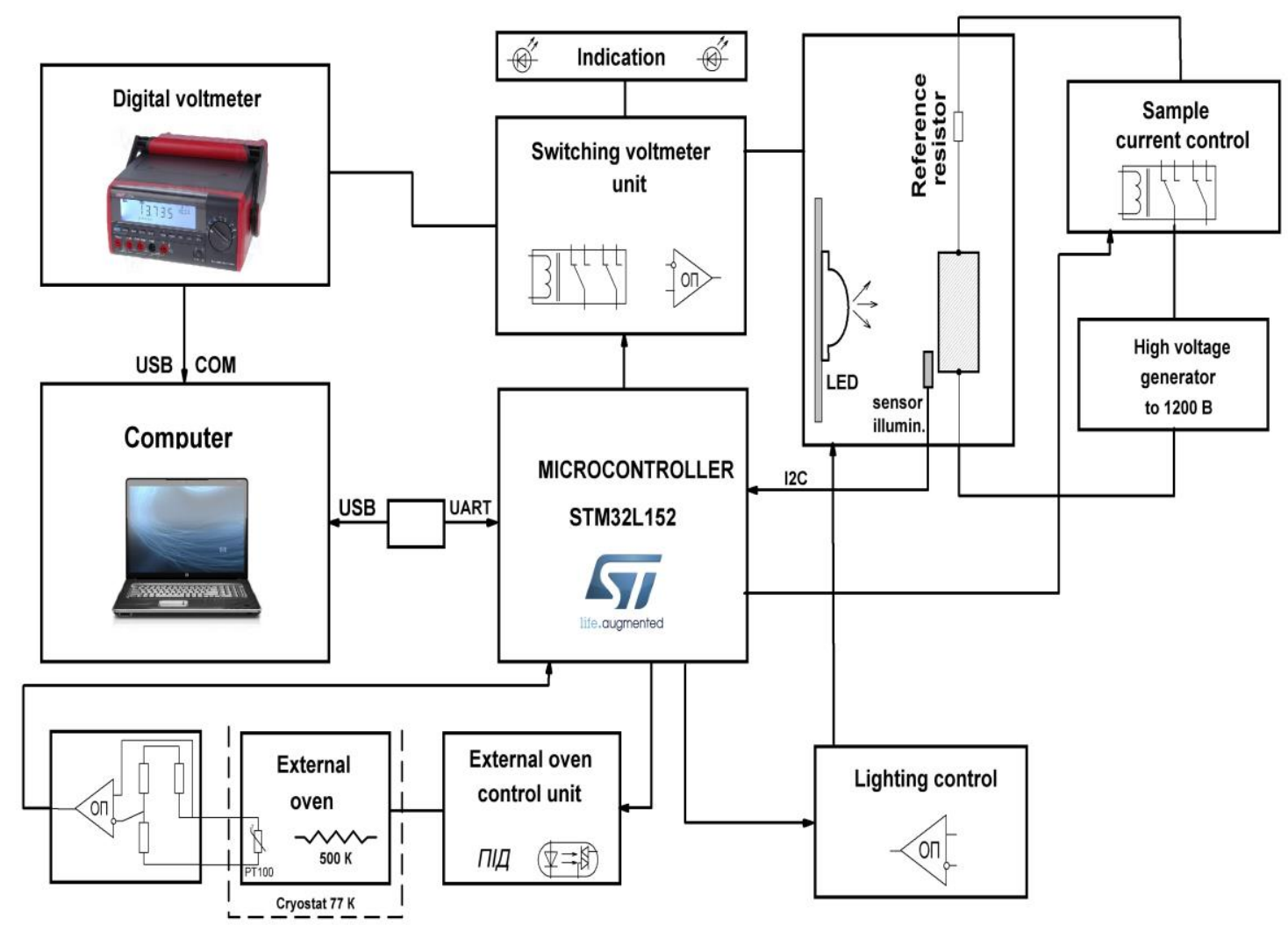

Fig. 2. Functional block diagram of the device of automated measurements of photoelectric parameters of high impedance semiconductor films. 


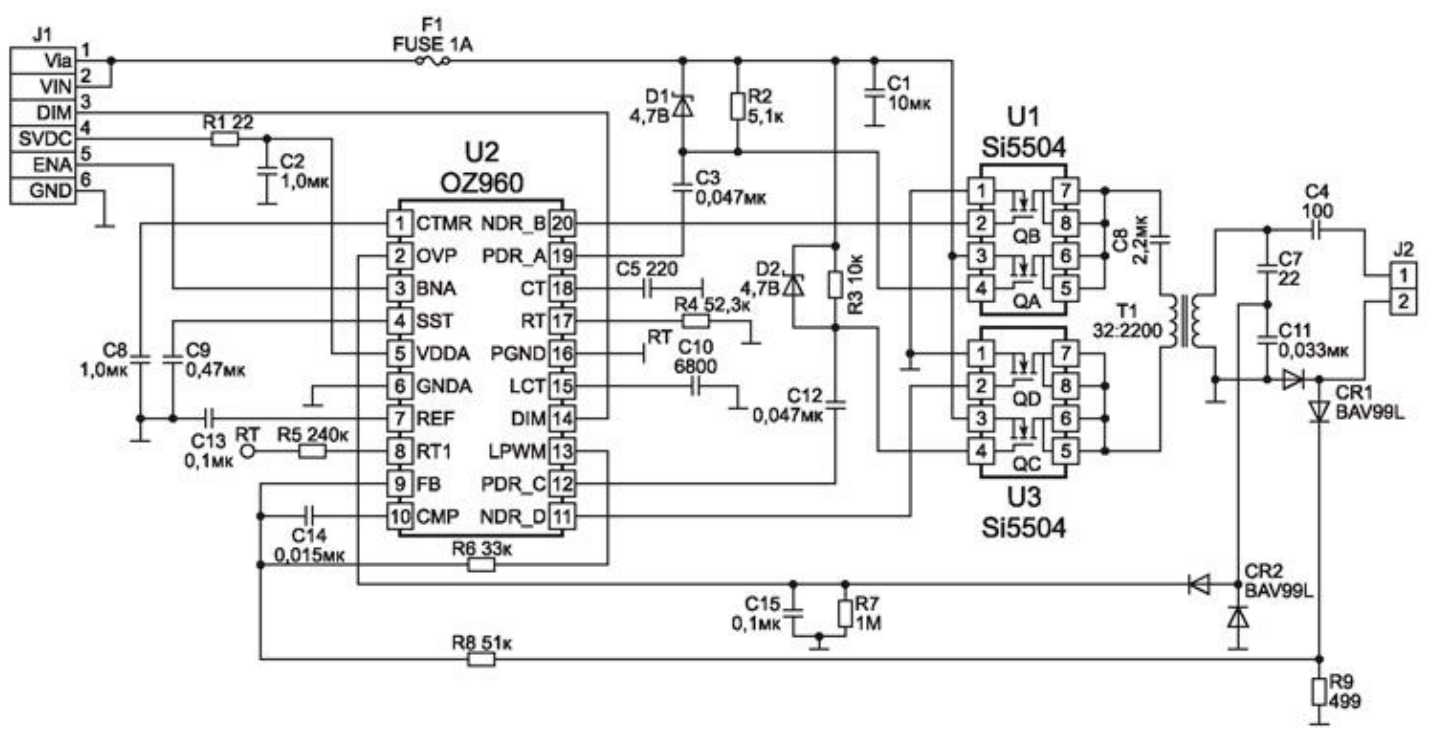

Fig. 3. Electric circuit diagram of the high voltage generation unit.

Turning on the LED and setting the required illumination are carried out by the DAC of the microcontroller via the current stabilizer on the operational amplifier (Fig. 4). The feedback is carried out both via LED current, resulting from the shunt, and illumination of the alternating digital I2C light sensor, in particular VEML7700CT, VEML6075. Changing the frequency of light radiation is carried out manually by replacing the LED.

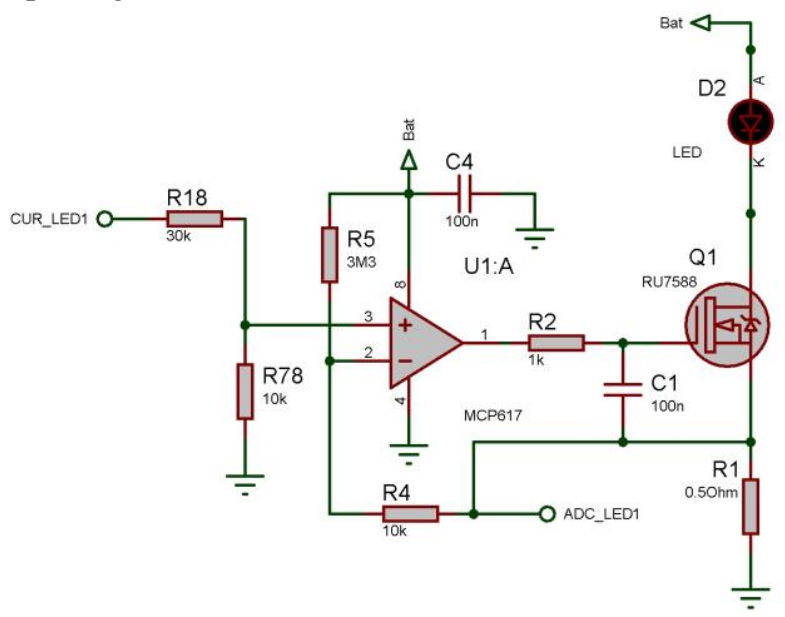

Fig. 4. Electric circuit of the LED current stabilizer.

The temperature is measured by the platinum thermistor RT100 included in the bridge circuit (Fig. 5), which is powered by a precision reference voltage source AD1583. In the shoulders of the bridge $0.1 \%$ SMD resistors with low temperature coefficient of resistance were used.

The heater control is provided by the triac regulator, with switching at the voltage transition through zero and optocoupler on the opto-triac MOS3031. Stabilization of the temperature of the external heater is carried out using a proportional algorithm.

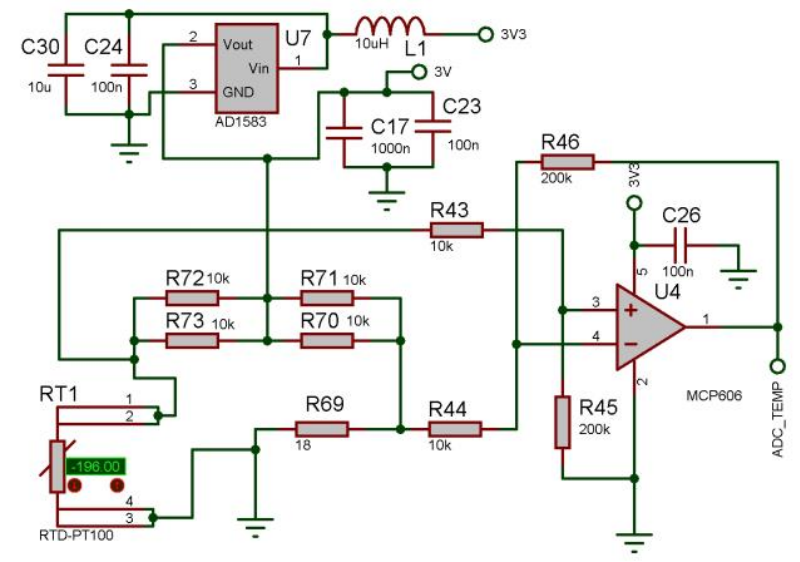

Fig. 5. Electric bridge circuit for measuring temperature.

Functional blocks are assembled on separate printed circuit boards, which are placed in enclosed aluminum cells of the grounded case and connected together by a shielded wire in order to minimize electromagnetic interference. For the same reason, the network transformers are closed with a metal cover, and the highvoltage part is put into a separate case and powered by the $6 \mathrm{~V}$ battery.

\section{III.Software implementation of the measurement process}

The program is written in the Delphi environment and provides digital voltmeter data recording, manual and automated measurement process control, data preprocessing and visualization.

The digital voltmeter transmits real-time measurement results via RS232 protocol (2400 bps, 7 bits). Data are received and decoded by the program and displayed on the screen, and the average value of the last ten measured values is calculated and displayed.

Between the controller and the computer there is a 
two-way exchange of information via the USB interface, device control and data request are carried out by sending commands and receiving the response after their execution.

In addition, in manual mode, the program allows you to control separate functional units independently, which makes it possible to set-up and perform a non-standard test with automatic or manual recording of results.

In automatic mode, the program allows both single measurements of electrical parameters (and with the automatic calculation of specific conductivity after entering the data about the geometric dimensions of the sample) and a series of measurements of time or temperature dependences with the construction of the temperature-time diagram of the planned measurements (Fig. 6). During measurements, visualization of time or temperature dependences of the selected parameters in the graphs is possible.

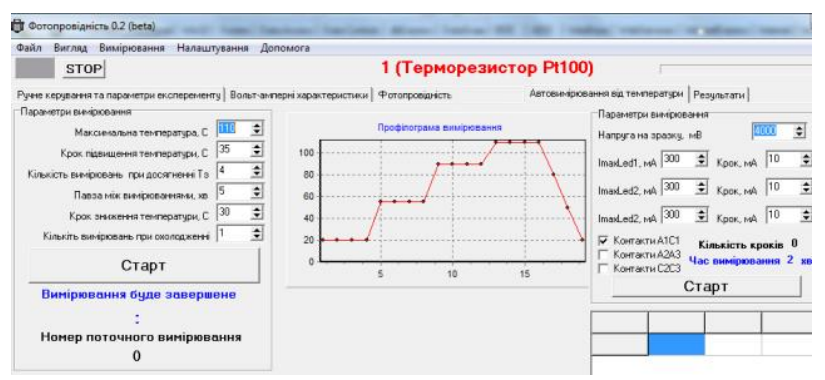

Fig. 6. General view of the window of the divice of automated measurements of the control program for the photovoltaic parameters of semiconductor films.

The measurement results of each sample are stored in a separate file with the possibility of further continuation of the experiment. The possibility to select specific data for export to MS Exel for further processing has been implemented. In future, it is planned to integrate with other devices for studing the parameters of semiconductors into a single database.

For a series of samples of different thicknesses, the automatic data filtering option and construction of profiles of electrical parameters are implemented.

\section{Results of test measurements of high impedance samples}

A series of measurements of test resistors with known resistance and accuracy was carried out, the results of all measurements up to $10 \mathrm{G} \Omega$ fit the passport accuracy for the measuring elements. For resistors up to $100 \mathrm{k} \Omega$, the error was $1 \%$, for resistors of 1-100 M $\Omega-$ $3 \%$, and the nominal $1-10 \mathrm{G} \Omega-5 \%$.

The configuration of the measured samples is shown in Fig. 1, silver contact pads are drawn as shaded rectangles, a gray rectangle represents high resistance film obtained by thermal evaporation in a vacuum. The results of measuring the current-voltage characteristic of real CdTe samples are shown in Fig. 7. We can see that up to a voltage of $600 \mathrm{~V}$ the current-voltage characteristic is linear and passes through the origin, giving a stable resistance of $300 \mathrm{G} \Omega$, with further increase in voltage, resistance of the sample decreases sharply to $150-120 \mathrm{G} \Omega$, which may be due to a micro breakdown in a polycrystalline sample.

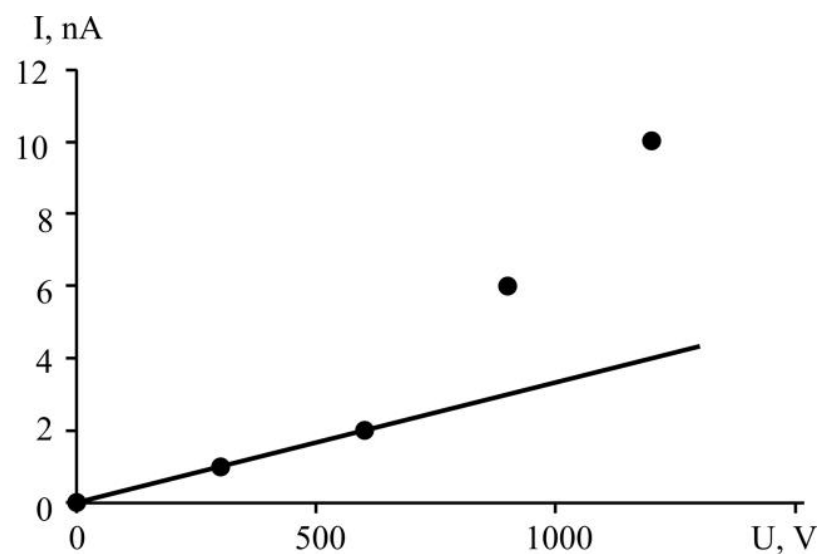

Fig. 7. Current-voltage characteristic of melting CdTe of thickness of $540 \mathrm{~nm}$.

Photoconductivity study was conducted at a voltage of $600 \mathrm{~V}$, the illumination was carried out with 3 Watt infrared LED with a wavelength of $940 \mathrm{~nm}$. Dependence of the specific resistance on the reduced illumination is shown in Fig. 8.

$\rho, 10^{7} \mathrm{Ohm} \mathrm{cm}$

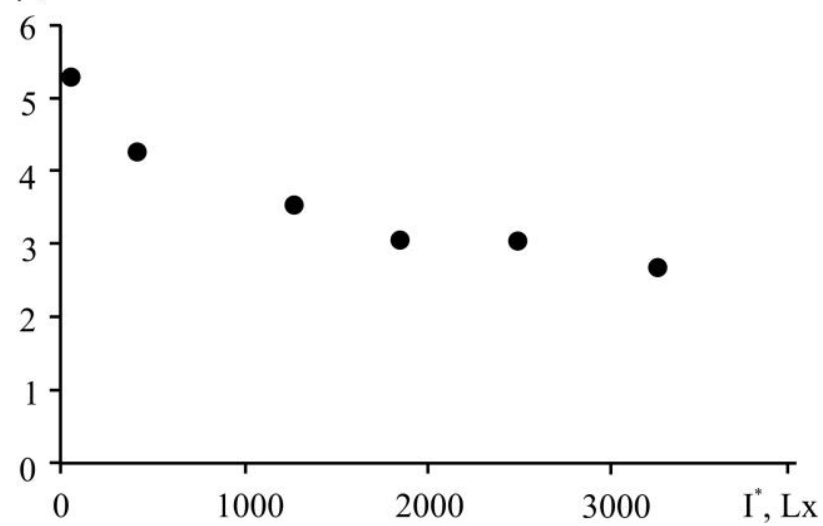

Fig. 8. Dependence of the specific resistance of CdTe film of the thickness of $540 \mathrm{~nm}$ on illumination.

Resistivity measurements are in good agreement with the data given in the literature sourses for films of the same chemical composition obtained by similar methods.

Through the use of modern element base and highly integrated circuits, it was possible to implement relatively simple and inexpensive circuitry and the design of the device, which allows us to use it not only for scientific research, but also in the educational process for performing laboratory works on semiconductor materials science. 


\section{Conclusions}

1. An electric circuit has been developed, and an operating device for measuring the electrical and photovoltaic parameters of high impedance semiconductor films has been designed.

2. A computer program that provides automation of measurements, registration and primary processing of data with possibility of plotting the graphs of time and temperature dependences has been created.
The work was partially carried out within the framework of a research project of the Ministry of Education and Science of Ukraine (state registration number is 0117U002407).

Dzundza B.S. - Ph.d, senior researcher; Prokopiv V.V. - professor, Ph.d, head of department; Mazur T.M. - postgraduate student; Yurchyshyn L.D. - PhD, editor

[1] D. M. Freik, V. M. Chobanyuk, L. I. Nikiruy, Physics and Chemistry of Solid State 7(3), 405 (2006).

[2] D. M. Freik, V. M. Chobanyuk, O. S. Krynitsky, I. V. Horichok, Physics and Chemistry of Solid State 13(3), 744 (2012).

[3] T. M. Razykov, K. M. Kuchkarov, B. A. Ergashev, A. Khubbimov, M. K. Khakkulov, Effect of chloride treatment on the electrophysical properties of CdTe films obtained by the XMPO method. Conference dedicated to the 80th anniversary of Academician M.S. Saidov (Tashkent, 2010). Pp. 265.

[4] E. V. Kuchis, Methods for studying the Hall effect (Soviet Radio, Moscow, 1974).

[5] N. F. Kovtonyuk, Measurement of parameters of semiconductor materials (Metallurgy, Moscow, 1970).

[6] Yu. V. Klevkov, S. A. Kolosov, A. F. Plotnikov, Physics and Technology of Semiconductors 41(6) 323 (2007).

Б.С. Дзундза, В.В. Прокопів, Т.М. Мазур, Л.Д. Юрчишин

\title{
Автоматизація вимірювань фотоелектричних параметрів високоімпедансних напівпровідникових плівок
}

\author{
Фізико-хімічний інститут ДВНЗ «Прикарпатський наџіональний університет імені Василя \\ Стефаника», вул. Шевченка, 57, Івано-Франківськ, 76000, Україна, E-mail: prkvv@i.uа
}

\footnotetext{
Описано методику вимірювання електропровідності та фотопровідності напівпровідникових плівок 3 високим електричним опором. Представлена електрична схема та розроблена комп’ютерна програма, що забезпечує автоматизацію вимірювань, реєстрацією і первинною обробку даних, 3 можливість побудови графіків часових залежностей для попереднього аналізу експериментальних даних вже в процесі вимірювання.
}

Ключові слова: електричні параметри, фотопровідність, автоматизація, мікроконтролер. 